\title{
Perlindungan Hukum Obyek Jaminan yang Tidak Didaftarkan Secara Fidusia Studi Kasus PT. Bima Multi Finance
}

\section{The Guarantee Object of Legal Protection which is not Fiduciary Registered: a Case Study of PT. Bima Multi Finance}

\author{
Asnal Laipa \\ Kantor Wilayah Kementerian Hukum dan HAM Sulawesi Tenggara \\ E-mail: asnallaipa.80@gmail.com \\ Muhammad Sjaiful \\ Pascasarjana Universitas Halu Oleo \\ E-mail:muhsjaiful@gmail.com \\ Safril Sofwan Sanib \\ Pascasarjana Universitas Halu Oleo \\ E-mail: safrilsanib@yahoo.com
}

\begin{abstract}
This study is aimed to analyze whether the fiduciary guarantee object which is not registered still can be coverred under law guarantee as a case study of PT. Bima Multi Finance Kendari, analyzed the result model in used on dispute resolution that already known can be done between the creditor with default debitur to the confisaction of collateral based on the paid agreement of PT. Bima Multi Finance. This study is a law study that used constitution approach and concepted as well, this study also answerred the problem of paid agreement between the creditor and the debitur included the motor vehicle guarantee without collateral imposition objects as fiduciary that can not get along under law guarantee if the default debitur, meanwhile the finance of PT. Bima Multi Finance is not registerred as fiduciary registration or just in part of the agreement fiduciary guarantee in hand.
\end{abstract}

Keyword: Guartantee; Protection; Fiduciary

Abstrak: Penelitian ini bertujuan menganalisis apakah obyek jaminan fidusia yang tidak didaftarkan dapat perlindungan hukum Studi kasus PT. BIMA Multi Finance Cabang Kendari, menganalisis model penyelesaian sengketa yang dapat dilakukan antara kreditur dengan debitur wanprestasi terhadap penyitaan barang jaminan menurut perjanjian pembiayaan di PT. Bima Multi Finance. penelitian ini adalah penelitian hukum yang menggunakan pendekatan perundang-undangan dan konseptual, penelitian ini menjawab masalah perjanjian pembiayaan antara kreditur dan debitur dengan jaminan kendaraan bermotor tanpa pembebanan jaminan benda secara fidusia tidak mendapatkan perlindungan hukum apabila debitur wanprestasi, namun lembaga 
pembiayaan di PT. Bima Multi Finance tidak melakukan pendaftaran secara fidusia atau hanya sebatas perjanjian jaminan fidusia secara di bawah tangan.

Kata kunci: Jaminan; Perlindungan; Fidusia

\section{PENDAHULUAN}

Lembaga keuangan dalam dunia keuangan bertindak selaku lembaga yang menyediakan jasa keuangan bagi nasabahnya, di mana pada umumnya lembaga ini diatur oleh regulasi keuangan dari pemerintah. Salah satu jenis lembaga keuangan adalah lembaga keuangan bukan bank. Menurut keputusan menteri keuangan No. KEP-38/MK/IV/1972, lembaga keuangan bukan bank atau yang disingkat menjadi LKBB merupakan sebuah badan yang melakukan kegiatan dalam hal keuangan baik secara langsung maupun tidak langsung, menghimpun dana dari masyarakat dengan mengeluarkan surat-surat berharga, selanjutnya menyalurkannya untuk pembiayaan investasi perusahaan yang membutuhkan pinjaman. ${ }^{1}$

Lembaga keuangan bukan bank ini mempunyai peranan sangat penting dalam dunia pembiayaan, kegiatan lembaga pembiayaan ini dilakukan dalam bentuk penyediaan dana atau barang modal dengan tidak menarik dana secara langsung dari masyarakat dalam bentuk giro, deposito, tabungan dan surat sanggup bayar ${ }^{2}$.

Kegiatan pinjam meminjam yang terjadi di masyarakat umum biasanya dengan syarat harus menyerahkan jaminan kepada pihak yang memberikan pinjaman. Jaminan utang tersebut dapat berupa barang/benda, jaminan benda yaitu jaminan yang memberikan hak kepada kreditur atas kebendaan milik kreditur, yakni hak untuk memanfaatkan benda tersebut jika debitur melakukan wanprestasi ${ }^{3}$. Yang termasuk jaminan kebendaan antara lain adalah hak gadai, hipotek dan fidusia. Menurut Stein dalam bukunya J. Satrio mengatakan bahwa pada waktu permulaan KUH Perdata memang lembaga jaminan gadai dan Hipotek sudah cukup memenuhi kebutuhan praktik penjaminan. Pada masa itu, lalu lintas kredit belum berkembang benda yang digadaikan terutama berupa benda seni dan perhiasan ${ }^{4}$.

1 ASLI RI, "Mengenal berbagai Lembaga Keuangan di Indonesia" ASLI RI, https://www.asliri.id/2018/12/17/mengenal-berbagai-lembaga-keuangan-di-indonesia/, diakses pada tanggal 10 Maret 2021.

2 Martinus Tjipto, Perlindungan Hukum terhadap kreditur dalam Perjanjian Fidusia secara di Bawah Tangan (penelitian pada PT. Olympindo Multi Finance Cabang Medan), Tesis, Medan: Pasca Sarjana Universitas Sumatera Utara, 2009, hlm. 1.

3 Frieda Husni Hasbullah, Hukum Kebendaan Perdata Jilid 2 Hak-Hak yang Memberi Jaminan, Jakarta: Ind Hill-Co, 2002, hlm. 16.

4 J. Satrio, Hukum Jaminan: Hak-HakJaminan Kebendaan, Bandung: Citra Aditya Bhakti, 1993, hlm. 9. 
Mempertegas pendapat di atas J. Satrio ${ }^{5}$ mengatakan bahwa problematik yang dihadapi dalam dunia usaha, yang menimbulkan kebutuhan akan adanya lembaga jaminan lain, selain gadai yaitu dibutuhkannya suatu lembaga jaminan, yang memungkinkan diberikannya benda bergerak sebagai jaminan, tetapi benda tersebut tetap berada dalam tangan dan tetap bisa dipakai untuk usaha si pemberi jaminan.

Keberadaan praktik fidusia di Indonesia sebelum diundangkannya Undang-Undang Nomor 42 Tahun 1999 tentang Jaminan Fidusia, dilandaskan pada aturan dari Negeri Belanda diakui oleh Hoge Raad mula-mula dalam Arrest tanggal 25 Januari 1929 (Bierbrouwerij Arrest). Sedang di Indonesia berdasarkan Arrest Hooggerechtshof tahun 1932 (BPM-Clynett Arrest) lahirlah yurisprudensi pertama tentang fidusia. ${ }^{6}$ Sementara itu dalam perkembangan yurisprudensi, Lembaga Fidusia di Indonesia untuk pertama kalinya mendapatkan pengakuan dalam keputusan HgH. Tanggal 18 Agustus 1932 dalam perkara antara B.P.M melawan Clignet.7 Dikatakan bahwa title XX Buku II kitab Undang-Undang Hukum Perdata memang mengatur tentang gadai, akan tetapi tidak menghalangi-halangi para pihak untuk mengadakan perjanjian yang lain daripada perjanjian gadai, bilamana perjanjian gadai tidak cocok untuk mengatur hubungan hukum antara mereka. Perjanjian fidusia dianggap bersifat memberikan jaminan dan tidak dimaksudkan sebagai perjanjian gadai. ${ }^{8}$

Lahirnya jaminan fidusia merupakan murni didasarkan pada ketentuan Pasal 1320 jo.1338 KUH Perdata mengenai kebebasan berkontrak. Tidak ada suatu standar baku mengenai syarat formal perjanjian fidusia. ${ }^{9}$ Tidak ada karakteristik lain yang umumnya terdapat pada suatu instrumen jaminan. Memenuhi kebutuhan masyarakat mengenai pengaturan jaminan fidusia sebagai salah satu sarana untuk membantu kegiatan usaha dan untuk memberi kepastian hukum kepada para pihak yang berkepentingan, maka pemerintah telah menetapkan Undang-Undang nomor 42 Tahun 1999 tentang Jaminan Fidusia pada tanggal 30 September 1999 dan Peraturan Pemerintah Nomor 86 tahun 2000 tentang tata cara pendaftaran jaminan fidusia ${ }^{10}$.

\footnotetext{
Ibid., hlm. 10.

6 Resty Femi Lombogia, “Perkembangan Lembaga Jaminan Fidusia di Indonesia”, Lex Privatum, Vol. 1, No. 4, Oktober 2013, hlm, 7.

7 Munir Fuady, Jaminan Fidusia (Cetakan Kedua Revisi), Bandung: Citra Aditya Bakti, 2003, hlm. 15.

8 Resty Femi Lombogia, Op. cit., hlm. 10.

9 Aria Suyudi, "Jaminan Fidusia dan Potensinya dalam Mendorong Laju Ekonomi", HukumOnline.com. https://www.hukumonline.com/berita/baca/hol907/jaminan-fidusia-dan-potensinya-dalammendorong-laju-ekonomi/, diakses pada tanggal 20 Februari 2021.

10 Martinus Tjipto, Op. cit., hlm. 8-9.
} 
Ketentuan di atas menentukan bahwa setiap perjanjian jaminan fidusia harus dibuat dengan akta notaris dan didaftarkan, maka perjanjian fidusia yang dibuat di bawah tangan yang hanya diketahui kedua belah pihak saja tidak mempunyai kekuatan sebagai perjanjian fidusia. Muhtar ${ }^{11}$ menyebutkan bahwa jaminan Fidusia harus didaftarkan, seperti yang diatur dalam pasal 11 Undang-Undang Jaminan Fidusia. Dengan adanya pendaftaran tersebut, UndangUndang Jaminan Fidusia memenuhi asas publisitas yang merupakan salah satu asas utama hukum jaminan kebendaan. Berdasarkan uraian tersebut, maka peneliti melakukan penelitian tesis dengan judul: "Perlindungan Hukum Obyek Jaminan yang Tidak Didaftarkan Secara Fidusia".

\section{METODE PENELITIAN}

Penelitian yang ini menggunakan penelitian hukum yaitu penelitian yang dilakukan dengan menganalisis permasalahan dengan menggunakan peraturan perundang-undangan, teori, asasasas hukum dan prinsip-prinsip hukum. Penelitian menganalisis ketentuan-ketentuan yang menjadi dasar dan landasan bagi permasalahan yang dibahas dengan melakukan studi kepustakaan dan penelitian lapangan dan menggunakan pendekatan perundang-undangan dan konseptual. Tipe penelitian yang digunakan yaitu penelitian doktrinal (Doctrinal Research) dan penelitian teoritik (Theoritical Research). Bahan hukum yang dikumpulkan dalam penelitian ini meliputi bahan hukum primer dan sekunder.

\section{ANALISIS DAN PEMBAHASAN}

\section{Perjanjian-perjanjian dalam Pembiayaan Konsumen}

Pelaksanaan perjanjian pembiayaan konsumen di Indonesia, pada dasarnya tidak hanya dibuat dalam satu macam perjanjian saja yang dibuat oleh para pihak, tetapi juga dibuat berbagai jenis perjanjian lainnya. Perjanjian pokoknya adalah perjanjian pembiayaan. Perjanjian pembiayaan merupakan perjanjian yang dibuat antara kreditur/pemberi fasilitas kredit dengan nasabah/ penerima fasilitas kredit dalam bentuk pemberian modal maupun untuk membiayai dalam pembelian kendaraan bermotor (roda dua). Masing-masing lembaga pembiayaan mempunyai jenis perjanjian pembiayaan konsumen yang berbeda-beda antara satu dengan lainnya. Perjanjian yang dibuat antara kreditur dan debitur yang terjadi pada PT. Bima Multi Finance Cabang Kendari yang diberi judul “ Perjanjian Pembiayaan Konsumen Multiguna”.

11 M. M. Muhtar, "Perlindungan Hukum Bagi Kreditur Pada Perjanjian Fidusia Dalam Praktek", Lex Privatum, Vol 1, No. 2, 2013, hlm 3. 
Dengan adanya perjanjian pembiayaan antara PT. Bima Multi Finance sebagai kreditur dan pihak debitur atau nasabah telah melahirkan hak dan kewajiban kedua belah pihak, dimana dengan lahirnya hak bagi salah satu pihak akan menjadi kewajiban bagi pihak lain. Begitu pula sebaliknya, lahir kewajiban salah satu pihak akan menjadi hak bagi pihak lain

Dalam perjanjian pembiayaan ini lahirlah perjanjian tambahan atau asesoir lainnya. Masing-masing lembaga pembiayaan mempunyai jenis perjanjian tambahan yang berbedabeda antar satu dengan lainnya. Yang dibuat oleh para pihak pada PT. Bima Multi Finance Cabang Kendari, yang diberi judul “ Perjanjian Kuasa Menjual.“

Perjanjian kuasa merupakan perjanjian yang dibuat antara pemberi kuasa dan penerima kuasa, dimana penerima kuasa diberi kewenangan untuk melakukan tindakan-tindakan hukum apabila pemberi kuasa lalai dalam melakukan kewajiban-kewajiban sesuai dengan pembiayaan konsumen. Pemberi kuasanya adalah penerima fasilitas/debitur, sedangkan penerima kuasanya adalah lembaga pembiayaan.

Menurut Pasal 1792 KUH Perdata, memberikan batasan, pemberian kuasa adalah suatu perjanjian, dengan mana seseorang memberikan kekuasaan kepada orang lain, yang menerimanya "untuk atas namanya”, menyelesaikan suatu pekerjaan.

Dalam surat kuasa tersebut disebutkan, bahwa selama hutang debitur belum dibayar lunas kepada penerima kuasa, kuasa ini tidak akan berakhir oleh karena sebab-sebab apa pun juga termasuk tetapi tidak terbatas oleh sebab-sebab yang tercantum dalam Pasal 1813, 1814 dan Pasal 1816 KUH Perdata. Adapun bunyinya adalah sebagai berikut:

Pasal 1813

Pemberian kuasa berakhir: dengan penarikan kembali kuasa penerima kuasa; dengan pemberitahuan penghentian kuasanya oleh penerima kuasa; dengan meninggalnya; pengampunan atau pailitnya; baik pemberi kuasa maupun penerima kuasa; dengan kawinnya perempuan yang memberikan atau menerima kuasa.

Pasal 1814

Pemberi kuasa dapat menarik kembali kuasanya jika hal itu dikehendaki, dan dapat memaksa pemegang kuasa untuk mengembalikan kuasa itu bila ada alasan untuk itu.

Pasal 1816

Penarikan kuasa yang hanya diberitahukan kepada penerima kuasa, tidak dapat diajukan kepada pihak ketiga yang telah mengadakan persetujuan dengan pihak penerima kuasa karena tidak mengetahui penarikan kuasa itu; hal ini tidak mengurangi tuntutan hukum dari pemberi kuasa terhadap penerima kuasa.

Berdasarkan definisi di atas memberi pengertian bahwa perjanjian pemberi kuasa adalah merupakan perjanjian sepihak. Kemudian makna kata-kata "untuk atas namanya" berarti bahwa yang diberi kuasa bertindak untuk dan atas nama pemberi kuasa, sehingga segala 
sebab dan akibat dari perjanjian ini menjadi tanggung jawab sepenuhnya dari pemberi kuasa dalam batas-batas kuasa yang diberikan (Pasal 1807 KUH Perdata) ${ }^{12}$.

\section{Perlindungan Hukum Kreditur Terhadap Obyek Jaminan yang Tidak Didaftarkan Secara}

\section{Fidusia}

Lembaga Pembiayaan konsumen dalam melakukan perjanjian atau surat kuasa dengan jaminan fidusia secara di bawah tangan, yang seharusnya dilakukan dengan akta notaris dan didaftarkan pada kantor pendaftaran fidusia untuk memperoleh sertifikat jaminan fidusia sesuai ketentuan undang-undang tentang jaminan fidusia, sehingga tindakan yang dilakukan oleh lembaga pembiayaan konsumen membuat jaminan fidusia secara di bawah tangan sangat mempengaruhi perlindungan hukum terhadap lembaga pembiayaan tersebut, dan persoalan yang sangat terkait dengan pembahasan penulis adalah berkaitan dengan pembuatan perjanjian pembiayaan kredit yang tidak didaftarkan secara fidusia. Rachellariny dan Cahyaningsih $^{13}$ dalam penelitiannya menyebutkan bahwa pelaksanaan eksekusi terhadap objek Lembaga Pembiayaan konsumen dalam melakukan perjanjian atau surat kuasa dengan jaminan fidusia secara di bawah tangan, yang seharusnya dilakukan dengan akta notaris dan didaftarkan pada kantor pendaftaran fidusia untuk memperoleh sertifikat jaminan fidusia sesuai ketentuan undang-undang tentang jaminan fidusia, sehingga tindakan yang dilakukan oleh lembaga pembiayaan konsumen membuat jaminan fidusia secara di bawah tangan sangat mempengaruhi perlindungan hukum terhadap lembaga pembiayaan tersebut, dan persoalan yang sangat terkait dengan pembahasan penulis adalah berkaitan dengan pembuatan perjanjian pembiayaan kredit yang tidak didaftarkan secara fidusia. Rachellariny dan Cahyaningsih menyebutkan bahwa pelaksanaan eksekusi terhadap objek Akibat hukum dari perjanjian pembiayaan konsumen yang dilakukan oleh PT. Bima Multi Finance hanya akan menjadi sebuah perjanjian Hutang Piutang biasa dan status kreditor dalam penyelesaian kredit bermasalah/kemacetan hanya sebagai kreditor konkuren (umum) sebagaimana dimaksud dalam Pasal 1131 KUH Perdata berbunyi: "semua kebendaan si berhutang baik yang bergerak dan tak bergerak, baik yang sudah ada maupun yang akan ada dikemudian hari, menjadi tanggungan untuk segala perikatan perseorangan debitur".

12 Djaja S. Meliala, Penuntut Praktis Perjanjian Pemberian Kuasa Menurut Kitab Undang-Undang Hukum Perdata, Bandung: Nuansa Aulia, 2008, hlm. 7.

13 Rachellariny, Rega Satya dan Cahyaningsih, "Eksekusi Obyek Jaminan Fidusia Yang Tidak Didaftarkan Dalam Lembaga Keuangan Non Bank (Studi Putusan Perkara Pengadilan Negeri Surakarta No.105/pdt/G/BPSK/2012/PN.Ska)". Privat Law, Vol. IV No. 2, 2016, hlm. 132-141. 
Dengan demikian berarti seluruh kebendaan milik debitur menjadi jaminan bagi semua kreditur dan apabila debitur tidak dapat memenuhi kewajiban utangnya kepada kreditur, maka segala kebendaan milik debitur tersebut akan dijual kepada umum dan terhadap hasil penjualan benda tersebut akan dilakukan pembagian di antara para kreditur secara seimbang dan sesuai dengan besarnya piutang masing-masing. ${ }^{14}$. Hak pemenuhan dari para kreditur yang demikian itu adalah sama dan sederajat satu dengan lainnya, tidak ada yang diutamakan. Mereka mempunyai hak bersama-sama terhadap seluruh harta kekayaan debitur, mereka disebut kreditur konkuren ${ }^{15}$.

Apabila PT. Bima Multi Finance melakukan perjanjian pembiayaan konsumen tanpa pembebanan jaminan dengan fidusia sebagaimana yang dimaksudkan dalam Undang-Undang Jaminan Fidusia Nomor 42 Tahun 1999 tidak akan mendapatkan perlindungan hukum dan justru akan membawa konsekuensi sebagai berikut:

1. Kedudukan kreditor bukan sebagai kreditor yang mendahulu (Preferent) sesuai perlindungan hukum yang diberikan oleh Pasal 27 Undang-Undang Jaminan Fidusia tetapi kedudukan kreditor hanya sebagai kreditor (konkuren) sesuai perlindungan hukum yang diberikan oleh Pasal 1131 KUH Perdata.

2. Obyek yang dijaminkan tidak bersifat mengikuti artinya kedudukan kreditor satu dan kreditor lainnya sama, memiliki hak yang sama untuk mendapatkan pelunasan atas hasil penjualan dari benda yang dimiliki oleh debitur, dalam hal ini ketentuan Pasal 1313 KUH Perdata tentang perjanjian laksana undang-undang bagi para pembuatnya akan dikesampingkan oleh ketentuan pasal 1131 KUH Perdata yang mengatur tentang harta yang sudah ada sedang ada maupun yang akan ada dikemudian hari menjadi jaminan atas utang debitur.

3. Asas spesialitas dan publisitas tidak terpenuhi sehingga tidak dapat mengikat pihak ketiga dan tidak memberikan kepastian hukum kepada pihak-pihak yang berkepentingan. Proses pembuatan perjanjian yang hanya melibatkan para pihak yang membuat perjanjian sehingga perjanjian yang dibuat tersebut hanya memberikan perlindungan hukum kepada para pihak tersebut. Sedangkan pihak ketiga yang tidak ikut terlibat dalam proses perjanjian tersebut tidak akan tunduk terhadap perjanjian yang dibuat oleh para pihak tersebut.

14 Gunawan Widjaja dan Ahmad Yani, Seri Hukum Bisnis Jaminan Fidusia, Jakarta : PT. RajaGrafindo Persada, 2001, hlm. 75.

15 Munir Fuady, Op. cit, hlm. 40. 
4. Pelaksanaan eksekusi hanya dapat dilakukan dengan metode negosiasi agar proses serah terima penyerahan barang jaminan dilakukan dengan sukarela. Proses negosiasi yang tidak selamanya berakhir dengan persetujuan/sukarela untuk melakukan penyerahan kembali benda yang diperjanjikan akan menimbulkan persoalan baik secara perdata maupun pidana dikarenakan masing-masing merasa berhak atas benda yang menjadi obyek perjanjian. Pengambilan secara paksa walaupun sudah diatur dalam klausul perjanjian dan para pihak harus tunduk untuk mengikuti klausul tersebut (sebagaimana dimaksud pada Pasal 1313 KUH Perdata) bertentangan dengan ketentuan perundang-undangan lainnya yaitu ketentuan pidana yang terdapat pada Pasal 404 (1) KUH Pidana berbunyi: "Diancam dengan pidana paling lama dua tahun, Barang siapa dengan sengaja menarik barang milik sendiri, atau kalau bukan demikian untuk pemiliknya dari orang lain yang memiliki hak gadai, hak menahan, pungut hasil atau pakai atasnya”.

\section{Perlindungan Hukum Obyek Jaminan Fidusia yang Tidak Didaftarkan Secara Fidusia dalam Kasus PT. Bima Multi Finance}

Penyelesaian perselisihan akibat debitur melakukan wanprestasi pada PT. Bima Multi Finance Cabang Kendari pada pasal 15 ayat (2) yang menyatakan bahwa "para pihak sepakat bahwa setiap perselisihan yang timbul dari dan/atau sehubungan dengan perjanjian ini, termasuk tetapi tidak terbatas pada setiap pertanyaan mengenai keberadaannya, keabsahannya, pengakhiran dari hak-hak atau kewajiban-kewajiban setiap pihak akan diselesaikan secara musyawarah untuk mufakat dalam jangka waktu 20 (dua puluh) hari kerja setelah penerimaan oleh salah satu pihak atas pemberitahuan dari pihak lainnya mengenai keberadaan perselisihan ${ }^{16 "}$.

Atas hal tersebut di atas, memberikan keterangan bahwa cara penyelesaian sengketa yang dilakukan oleh PT. BIMA Multi Finance dilakukan dengan cara pihak kreditur akan mengajak atau mengundang pihak debitur untuk bermusyawarah tentang permasalahan guna menemukan jalan terbaik bagi pihak kreditor maupun pihak debitur. Penyelesaian yang dapat dilakukan dengan berdiskusi dan saling keterbukaan dari para pihak maka akan ditemukan upaya damai dalam penyelesaian perjanjian kredit tersebut sehingga tidak ada pihak menderita kerugian.

16 Wawancara dengan Bapak Theo Sofian selaku Marketing Head pada PT. Bima Multi Finance Tanggal, 5 Januari 2021 
Pasal 15 ayat (3) perjanjian pembiayaan multiguna PT. Bima Multi Finance menyatakan bahwa: "apabila penyelesaian secara musyawarah untuk mufakat tidak tercapai, para pihak setuju untuk menyerahkan penyelesaian perselisihan yang ada melalui Lembaga Alternatif Penyelesaian Sengketa (LAPS) pada Badan Mediasi Pembiayaan dan Pegadaian Indonesia (BMPPI)".

Hal yang dilakukan oleh kreditur dan debitur dalam penyelesaian perselisihan jika penyelesaian secara musyawarah untuk mufakat tidak tercapai maka berdasarkan Pasal 15 perjanjian pembiayaan multiguna akan memilih penyelesaian perselisihan sengketa yakni Lembaga Alternatif Penyelesaian Sengketa (LAPS) pada Badan Mediasi Pembiayaan dan Pegadaian Indonesia (BMPPI) yang kedudukan di Jakarta. Namun sampai saat ini belum ada kasus yang penyelesaian sengketa antara PT. Bima Multi Finance sebagai kreditur dan debitur menggunakan Lembaga Alternatif Penyelesaian Sengketa (LAPS) tersebut, hal ini dikarenakan semua proses penyelesaian sengketa yang terjadi pada PT. Bima Multi Finance sebagai kreditur dan debitur selalu berakhir dengan proses musyawarah ${ }^{17}$.

\section{Penyelesaian Sengketa Dengan Cara Litigasi}

Berdasarkan Pasal 15 ayat (3) perjanjian pembiayaan multiguna PT. Bima Multi Finance menyatakan bahwa: “ apabila penyelesaian secara musyawarah untuk mufakat tidak tercapai, para pihak setuju untuk menyerahkan penyelesaian perselisihan yang ada melalui 1) Lembaga Alternatif Penyelesaian Sengketa ( LAPS) pada Badan Mediasi Pembiayaan dan Pegadaian Indonesia (BMPPI), 2) Pengadilan Negeri Jakarta Pusat namun dengan tidak mengurangi hak debitur untuk mengajukan tuntutan hukum terhadap kreditur ${ }^{18 " .}$

Hal yang ditempuh oleh kreditur dan debitur dalam penyelesaian perselisihan jika penyelesaian secara musyawarah dan Lembaga Alternatif Penyelesaian Sengketa ( LAPS) pada Badan Mediasi Pembiayaan dan Pegadaian Indonesia (BMPPI) tidak tercapai maka akan maka kedua belah pihak telah sepakat untuk menyerahkan penyelesaian perselisihan sengketa melalui Pengadilan Negeri Jakarta Pusat. Penentuan tempat kedudukan hukum dalam

\footnotetext{
17 Wawancara dengan Bapak Theo Sofian selaku Marketing Head pada PT. Bima Multi Finance Tanggal, 5 Januari 2021

18 Wawancara dengan Bapak Theo Sofian selaku Marketing Head pada PT. Bima Multi Finance Tanggal, 5 Januari 2021
} 
mengajukan gugatan kedua belah pihak telah sepakat untuk tidak mengajukan di pengadilan dimana tempat kedua belah pihak berada. ${ }^{19}$

\section{KESIMPULAN}

Perjanjian pembiayaan konsumen yang dilakukan oleh PT. Bima Multi Finance, tanpa ditidak lanjuti dengan pembebanan benda secara fidusia dan tidak dibuatkan akta notaris serta tidak didaftarkan pada kantor pendaftaran fidusia tidak mendapatkan perlindungan hukum. Perlindungan dalam hal: 1) tidak Memberikan kedudukan yang mendahului kepada kreditor penerima Fidusia terhadap kreditor lainnya (Pasal 27 UUJF), 2) tidak memenuhi spesialitas dan publisitas sehingga tidak mengikat pihak ketiga dalam memberikan jaminan kepastian hukum kepada pihak-pihak yang berkepentingan (Pasal 6 dan Pasal 11 UUJF), 3) tidak mendapatkan titel eksekutorial (Pasal 29 UUJF). Penyelesaian sengketa yang dapat dilakukan antara kreditur dengan debitur wanprestasi terhadap penyitaan barang jaminan menurut perjanjian pembiayaan di PT. Bima Multi Finance melalui musyawarah untuk mufakat. Apabila penyelesaian secara musyawarah tidak tercapai akan menggunakan Lembaga Alternatif Penyelesaian Sengketa (LAPS) pada Badan Mediasi Pembiayaan dan Pegadaian Indonesia (BMPPI), jika penyelesaian sengketa melalui Lembaga Alternatif Penyelesaian Sengketa ( LAPS) tidak tercapai kedua belah pihak bersepakat menyelesaikan melalui Pengadilan Negeri Jakarta Pusat.

\section{Daftar Pustaka}

\section{Buku}

Fuady, Munir, Jaminan Fidusia (Cetakan Kedua Revisi), Bandung: Citra Aditya Bakti, 2003.

Hasbullah, Frieda Husni, Hukum Kebendaan Perdata Jilid 2 Hak-Hak yang Memberi Jaminan, Jakarta: Ind Hill-Co, 2002.

Meliala, Djaja S., Penuntut Praktis Perjanjian Pemberian Kuasa Menurut Kitab Undang-Undang Hukum Perdata, Bandung: Nuansa Aulia, 2008.

Satrio, J., Hukum Jaminan: Hak-HakJaminan Kebendaan, Bandung: Citra Aditya Bhakti, 1993.

Widjaja, Gunawan dan Ahmad Yani, Seri Hukum Bisnis Jaminan Fidusia, Jakarta : PT. RajaGrafindo Persada, 2001.

19 Wawancara dengan Bapak Theo Sofian selaku Marketing Head pada PT. Bima Multi Finance Tanggal, 5 Januari 2021 


\section{Jurnal dan Makalah}

Lombogia, Resty Femi, "Perkembangan Lembaga Jaminan Fidusia di Indonesia”, Lex Privatum, Vol. 1, No. 4, Oktober 2013.

Muhtar, M. M., “Perlindungan Hukum Bagi Kreditur Pada Perjanjian Fidusia Dalam Praktek”, Lex Privatum, Vol 1, No. 2, 2013.

Rachellariny, Rega Satya dan Cahyaningsih, "Eksekusi Obyek Jaminan Fidusia Yang Tidak Didaftarkan Dalam Lembaga Keuangan Non Bank (Studi Putusan Perkara Pengadilan Negeri Surakarta No.105/pdt/G/BPSK/2012/PN.Ska)". Privat Law, Vol. IV No. 2, 2016.

Tjipto, Martinus, Perlindungan Hukum terhadap kreditur dalam Perjanjian Fidusia secara di Bawah Tangan (penelitian pada PT. Olympindo Multi Finance Cabang Medan), Tesis, Medan: Pasca Sarjana Universitas Sumatera Utara, 2009.

\section{Peraturan Perundang-undangan}

Undang-Undang Dasar Negara Republik Indonesia 1945.

Kitab Undang-Undang Hukum Perdata.

Undang-Undang Nomor 42 Tahun 1999 tentang Jaminan Fidusia.

Undang-Undang Nomor 14 Tahun 2014 tentang Jabatan Notaris.

Undang-Undang Nomor 30 tahun 1999 tentang Arbitrase dan Alternatif Penyelesaian Sengketa. Peraturan Pemerintah Nomor 21 Tahun 2015 tentang Tata Cara Pendaftaran Fidusia dan biaya Pembuatan Akta Jaminan Fidusia.

Peraturan Pemerintah Nomor 28 Tahun 2019 tentang Tarif Atas Jenis Penerimaan Negara Bukan Pajak yang Berlaku pada Kementerian Hukum dan HAM Republik Indonesia.

Keputusan Presiden Nomor 139 Tahun 2000 tentang Pembentukan Kantor Pendaftaran Fidusia di Setiap Ibu Kota Provinsi di Wilayah Negara Republik Indonesia.

Peraturan Menteri Hukum dan HAM Nomor 10 Tahun 2013 tentang Tata Cara Pendaftaran Jaminan Fidusia Secara Elektronik.

\section{Situs Web}

ASLI RI, "Mengenal berbagai Lembaga Keuangan di Indonesia" ASLI RI, https://www.asliri.id/2018/12/17/mengenal-berbagai-lembaga-keuangan-diindonesia/, diakses pada tanggal 10 Maret 2021.

Suyudi, Aria, "Jaminan Fidusia dan Potensinya dalam Mendorong Laju Ekonomi", HukumOnline.com. https://www.hukumonline.com/berita/baca/hol907/jaminan- 
fidusia-dan-potensinya-dalam-mendorong-laju-ekonomi/, diakses pada tanggal 20 Februari 2021. 